\title{
Differential expression of estrogen receptor subtypes and variants in ovarian cancer: effects on cell invasion, proliferation and prognosis
}

Karen K. L. Chan ${ }^{1 *}$, Michelle K. Y. Siu', Yu-xin Jiang ${ }^{1}$, Jing-jing Wang ${ }^{1}$, Yan Wang ${ }^{3}$, Thomas H. Y. Leung ${ }^{1}$, Stephanie S. Liu', Annie N. Y. Cheung ${ }^{2}$ and Hextan Y. S. Ngan ${ }^{1}$

\begin{abstract}
Background: Due to the presence of both classical estrogen receptor (ERa) and another ER subtype (ER $\beta$ ) in ovarian cancer, hormonal treatment is an attractive option. However, response to tamoxifen in ovarian cancer is modest. The presence of ER $\beta$ variants further complicated the issue. We have recently shown that specifically targeting ER subtypes using selective ER modulators showed opposing functions of ER subtypes on cell growth. In the present study, the clinical significance of ERa and ER $\beta$ variants $(\beta 1, \beta 2$ and $\beta 5)$ and the functional effects of ER $\beta 2$ and ER 35 in ovarian cancer was investigated.
\end{abstract}

Methods: ERa, ERß1, ERß2 and ERß5 expression were evaluated by immunohistochemistry in 106 ovarian cancer tissues. The association between ERs expression and clinicopathological parameters or prognosis was analyzed. Ectopic expression of ERß2 and ERß5 followed by functional assays were performed in ovarian cancer cell lines in order to detect their effects on cell invasion and proliferation.

Results: We found significantly higher nuclear (n)ERa and nERß5 and lower cytoplasmic (c)ERa expression in advanced cancers. Significantly lower ERß1 expression was also detected in high grade cancers. Significant loss of nERa and cER 32 expression were observed in clear cell histological subtypes. Higher nERß5 and lower cERß5 expression were associated with serous/clear cell subtypes, poor disease-free and overall survival. Positive cERa and higher cERß1 expression were significantly associated with better disease-free and overall survival. Furthermore, we found nER $\beta 5$ as an independent prognostic factor for overall survival. Functionally, overexpression of ERß5 enhanced ovarian cancer cell migration, invasion and proliferation via FAK/C-Src activation whereas ERß2 induced cell migration and invasion.

Conclusions: Since tamoxifen binds to both ERa and ERß1 which appear to bear opposing oncogenic roles, the histotypes-specific expression pattern of ERs indicates that personalized treatment for women based on ERs expression using selective estrogen receptor modulators may improve response rate. This study also suggests nERß5 as a potential prognostic marker and therapeutic target in ovarian cancer.

Keywords: Estrogen receptors, Ovarian cancer, Prognostic marker, Cell invasion and proliferation

\footnotetext{
* Correspondence: kklchan@hku.hk

'Department of Obstetrics and Gynaecology, The University of Hong Kong,

Queen Mary Hospital, Hong Kong, HKSAR, China

Full list of author information is available at the end of the article
}

\section{Biomed Central}

(c) The Author(s). 2017 Open Access This article is distributed under the terms of the Creative Commons Attribution 4.0 International License (http://creativecommons.org/licenses/by/4.0/), which permits unrestricted use, distribution, and reproduction in any medium, provided you give appropriate credit to the original author(s) and the source, provide a link to the Creative Commons license, and indicate if changes were made. The Creative Commons Public Domain Dedication waiver (http://creativecommons.org/publicdomain/zero/1.0/) applies to the data made available in this article, unless otherwise stated. 


\section{Background}

Ovarian cancer contributes to high mortality among all gynecological malignancies [1]. Primary treatment mainly involves cytoreductive surgery and adjuvant chemotherapy. Recurrences are common, albeit most patients have initial response. Thus, the overall prognosis is poor [2]. Although second line chemotherapy has overall 20-30\% response rates, there are significant side effects. Hormonal therapy has relatively few side effects, making it as an attractive treatment option. Ovarian cancer is considered as a hormone-responsive cancer with estrogen receptors (ERs) expressed in about $60-100 \%$ of ovarian cancers [3]. Tamoxifen is a well-known selective estrogen receptor modulator (SERM) treatment for breast cancer. However, it only has a modest response rate $(10-15 \%)$ in ovarian cancer [4]. It is crucial to unravel the way to make hormonal therapy more effective in ovarian cancer.

Estrogen acts via ERs. Another ER subtype (ER $\beta)$, which was discovered in 1996, was genetically different from the classical ER $\alpha[5,6]$. They differ not only in their tissue distribution, but also their ligand binding specificity and affinity [7]. We and others have found $E R \alpha$ and $E R \beta$ expression in normal and cancerous ovarian tissues $[8,9]$, with reduced ER $\beta$ expression when tumor progresses $[8,9]$. Our recent study using ovarian cancer cell lines treated with specific SERMs showed opposing functions of ER subtypes on cell growth, suggesting specifically targeting ER subtypes using SERMs may offer women a new option when ER subtypes expression is known [10].

Besides subtypes, the presence of ER $\beta$ variants ( $\beta 1-\beta 5)$ due to alternative splicing further complicate the biological significance of ER $\beta$ signaling [11]. ER $\beta 1$ is the only isoform capable of binding ligands [11]. So, ER $\beta$ agonists and antagonists only bind ER $\beta 1$. ER $\beta 3$ is testisspecific [12]. Although ER $\beta 2$ and ER $\beta 5$ cannot bind ligands, they can heterodimerize with ER $\beta 1$ and induce its transcriptional activity ligand-dependently [11]. Differential expressions of $E R \beta 1, E R \beta 2$ and $E R \beta 5$ were found in colorectal, breast, endometrial and prostate carcinomas [13-16]. In prostate cancer, high ER $\beta 2$ expression was associated with poor prognosis [17].

Other than the classical genomic pathway, cytoplasmic ERs are also known to exert effects through nongenomic signaling [18]. In lung cancer cells, ER $\beta$ was found to have mainly non-genomic actions where ER $\beta$ was found in cytoplasm and could not translocate to the nucleus [19]. Moreover, ER $\beta 2$ has been found to be a significant prognostic marker in breast cancer with distinct outcome by nuclear and cytoplasmic expression, suggesting the importance of its subcellular functions [14].

A number of previous studies investigated prognostic roles of ERs in ovarian cancer, but the findings were controversial $[8,20-22]$. A recent study found ER $\alpha$ is independent prognostic markers for endometrioid ovarian cancers [23]. Moreover, knowledge of ERs in ovarian caner with different histological subtypes is limited [3]. To the best of our knowledge, the present study is the only work assessing the subcellular expression of ER $\alpha$, $E R \beta 1, E R \beta 2$ and ER $\beta 5$ in a well-validated cohort of different histotypes of ovarian cancers with complete follow-up data, using specific well-validated antibodies. The effects and downstream signaling of ER $\beta 2$ and ER $\beta 5$ on ovarian cancer cell invasion and proliferation were further investigated.

\section{Methods}

\section{Clinical samples}

One hundred and-six paraffin-embedded tissue blocks of ovarian cancer were obtained from Department of Pathology, University of Hong Kong, Queen Mary Hospital. All patients underwent surgery with the age range between 32 to 78 years (mean 50.2 years) and the follow-up period range between five to 209 months (mean 62 months). Seventy-six patients also received platinum/paclitaxel chemotherapy. To confirm diagnosis, all samples were histologically reviewed.

\section{Cell lines and subcellular protein extraction}

Immortalized ovarian epithelial cell lines (HOSE 6-3, HOSE 11-12 and HOSE 17-1) and ovarian cancer cell lines (SKOV-3, OVCAR-3, OVCA 420, OVCA 429, OVCA 433, ES2, TOV-21G and TOV112D) were cultured as previously described $[24,25]$. SKOV-3, OVCAR-3, ES2, TOV-21G and TOV112D were purchased from American Type Culture Collection (ATCC; Manassas, VA). Others were given by Prof. S.W. Tsao (Department of Anatomy, University of Hong Kong). Nuclear and cytoplasmic extracts from SKOV-3 cells were isolated as previously described $[24,25]$.

\section{Plasmids, transfection of ER $\beta 2$ and ER $\beta 5$, treatment with FAK inhibitor}

Full-length sequences of $E R \beta 2$ and $E R \beta 5$ were assembled from synthetic oligonucleotides by GeneArt Gene Syntheses and cloned into pcDNA3.1 V5-His A (Life technologies, Waltham, MA). The final constructs were verified by sequencing and transfected along with the control vector into ES-2, OVCA420 and TOV-21G cells using Lipofectamine 3000 (Life technologies) and then selected with G418 $(800 \mu \mathrm{g} / \mathrm{ml})$ (Life technologies) [24, 25]. For FAK inhibitor treatment, ER 35 overexpressing cells were plated $24 \mathrm{~h}$ before treating with the FAK inhibitor 14 (5 $\mu \mathrm{M}$; Santa Cruz, Santa Cruz, CA) or vehicle (water). After $24 \mathrm{~h}$, cells were harvested for immunoblotting. 


\section{Immunohistochemistry}

Immunohistochemistry was done on formalin-fixed, paraffin-embedded sections using EnVision + Dual Link System (K4061; Dako, Carpinteria, CA) as previously described [24, 25]. Antigen retrieval was done by heating in a pressure cooker with $1 \mathrm{mM}$ EDTA ( $\mathrm{pH}$ 8.0) (for $E R \alpha, E R \beta 1$ and $E R \beta 2$ ) or citrate buffer ( $\mathrm{pH}$ 6.0) (for ER $\beta 5$ ). Antigen were detected with antibodies against $E R \alpha, E R \beta 1, E R \beta 2$ and ER $\beta 5$ (Additional file 1: Table S1). All four antibodies have been used/validated for immunohistochemical staining in paraffin-embedded tissue sections $[14,22]$. Both the intensity $(0=$ negative, 1 = faint, 2 = moderate, and $3=$ strong) and percentage $(0=<5 \%), 1=5 \%-25 \%, 2=26 \%-50 \%, 3=51 \%-75 \%$ and $4=>75 \%)$ of stained epithelial cells were assessed semiquantitatively as previously described [24, 25]. A composite "Histoscore" was determined by multiplying the staining intensity by the percentage of stained cells with 12 as the maximum score. The "histoscores" cut off at mean was used to define high and low expression levels of target genes.

\section{Immunoblotting}

Protein lysate was subjected to SDS-PAGE, transferred to PVDF membrane, and probed with antibodies as listed in Additional file 1: Table S1 and appropriate secondary antibodies as previously described [10, 24, 25]. Imaging of the bands were detected with ECL Plus detection system.

\section{Wound healing assay}

ES-2 cells were seeded in six-well plates for $24 \mathrm{~h}$. A wound was made by a sterile pipette tip. Photographs were taken at time 0 and $7 \mathrm{~h}$ to observe the closure of the wound as previously described [24].

\section{In vitro migration and invasion assays}

Cells $\left(1.25 \times 10^{5}\right)$ were plated on the upper side of a Transwell chamber (Corning, Tewksbury, MA) coated with or without Matrigel and then migrated or invaded through the membrane as previously described [24, 25]. After 7 (ES-2), $16 \mathrm{~h}$ (TOV-21G) or $24 \mathrm{~h}$ (OVCA420), cells on the upper compartment were removed. Migrated or invaded cells on the lower compartment were fixed, stained, and counted. For FAK inhibitor treatment, cells plated on the upper compartment for $6 \mathrm{~h}$ were treated with FAK inhibitor 14 $(5 \mu \mathrm{M})$ or vehicle $[24,25]$.

\section{Cell count method, XTT assay and focus formation assay}

For cell count method, cells $\left(3 \times 10^{4}\right)$ were cultured in growth medium in 12-well or 6-well plates or T150 culture flasks as previously described [24]. After $24 \mathrm{~h}$, cells were treated with $5 \mu \mathrm{M}$ FAK inhibitor 14 or vehicle. Luna $^{\mathrm{mm}}$ automated cell counter (Logos Biosystems,
Annandale, VA) was used to count cell number at days 1 (12-well culture plates), 4 (6-well culture plates), 8 and 11 (T150 culture flasks) for ES-2 and days 1, 5, 9 and 11 for OVCA 420. For XTT assay (Roche), cells (2000 cells/well) were cultured in 96-well plates. $50 \mu \mathrm{l} /$ well XTT labeling mixture was added at day 5 . After $4 \mathrm{~h}$ incubation at $37^{\circ} \mathrm{C}$, cell viability was evaluated by assessing the absorbance at $492 \mathrm{~nm}$.For focus formation assay, cells (2500) were seeded in 6-well culture plates and maintained in growth medium with fresh medium changed every 3 days. At day 9 , cells were stained with $1 \%$ crystal violet (Sigma-Alrich). Numbers of foci were counted.

\section{Statistical analysis}

SPSS 20 for Windows was used (SPSS Inc., Chicago, IL). Data between two groups was compared using Man$\mathrm{n}$-Whitney test. Data among multiple groups was compared using Kruskal-Wallis rank test.For survival analysis, Kaplan-Meier analysis and log-rank test were done. For multivariate survival analysis, Cox regression analysis was performed. For correlation analysis, Spearman's rho test was used. $P$ values $<0.05$ were considered statistically significant.

\section{Results}

Distinct subcellular localization patterns of ERs in ovarian cancers

By immunohistochemistry, we demonstrated distinct subcellular localization patterns of ER $\alpha, E R \beta 1, E R \beta 2$ and ER $\beta 5$ in ovarian cancers (Figs. 1 and 2). Most of ER $\alpha$ (72\%) was localized in the nucleus of ovarian cancers, but certain portion of ER $\alpha$ (16.7\%) also resided in the cytoplasm (Fig. 1a). All ovarian cancers displayed all three ER $\beta$ variants in the nucleus, and 93,96 and $68 \%$ of samples showing cytoplasmic ER $\beta 1, E R \beta 2$, and ER $\beta 5$ staining, respectively (Figs. $1 \mathrm{~b}$ and 2 ). Moreover, nER $\beta 1$ $(P=0.041)$ immunoreactivities in metastatic foci was statistically lower than their corresponding primary carcinomas (Additional file 2: Figure S1).

\section{Correlation of ERs expression with clinicopathological parameters in ovarian cancer}

To evaluate the clinicopathologic significance of ERs in ovarian cancer, "Histoscores" was analyzed with patients' clinicopathologic parameters (Tables 1 and 2). Higher $\mathrm{nER} \alpha(P=0.012)$ and $\mathrm{nER} \beta 5(P=0.03)$ as well as lower $\operatorname{cER} \alpha(P=0.016)$ expressions were significantly associated with advanced stages (stages III-IV). Significantly lower cER $\beta 1(P=0.034)$ expression was detected in stage IV carcinomas. Lower nER $\beta 1 \quad(P=0.046)$ and $\mathrm{cER} \beta 1$ $(P=0.046)$ expressions were significantly associated with poor histological differentiation (grade 3). nER $\alpha$ $(P<0.001)$ and $\operatorname{cER} \beta 2(P=0.001)$ expressions were significantly overexpressed in non-clear cell histological 


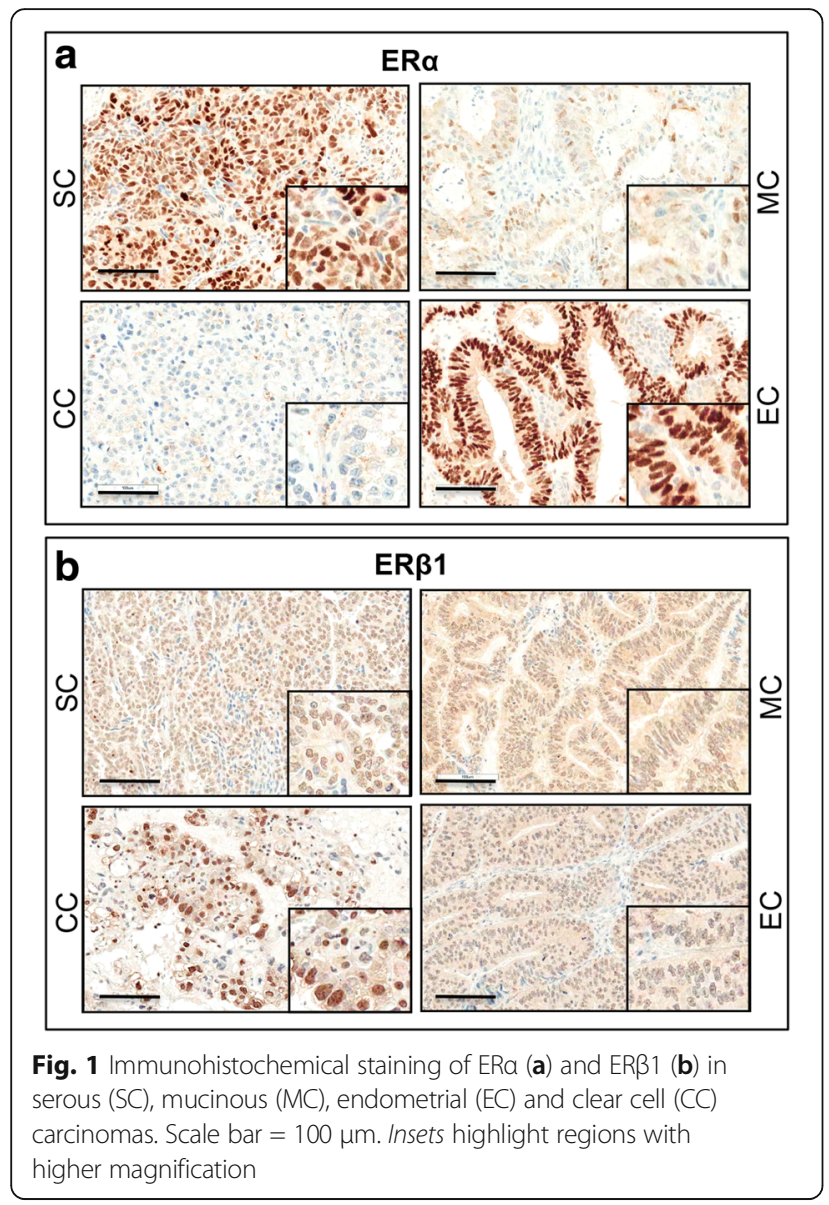

subtypes. Significantly higher $\mathrm{nER} \beta 1(P=0.003)$ and nER $\beta 5(P=0.039)$ as well as lower cER $\beta 5(P=0.013)$ expressions were found in serous/clear cell histological subtypes.

Association between ERs expression and clinical outcome Univariate Kaplan-Meier-survival analysis demonstrated better overall and disease-free survival for $\mathrm{cER} \alpha$ positive $(P=0.027$ and $P=0.035$; Fig. 3a) and high cER $\beta 1$ expression $(P=0.014$ and $P=0.021$; Fig. $3 \mathrm{~b})$ ovarian cancers. Interestingly, we found inverse relation between nuclear and cytoplasmic ER $\beta 5$ with survival. Significantly association was detected in high nER $\beta 5(P=0.007$ and $P=0.004$; Fig. $3 \mathrm{c}$ ) and low cER $\beta 5$ (both $P=0.032$; Fig. 3d) expression with poor overall and disease-free survival. For overall survival, nER $\beta 5$, stage and chemosensitivity were significant predictors by multivariate analysis (all $P<0.05$, Table 3 ).

\section{ERs correlations}

Spearman's $\rho$ test was performed to find correlations between ERs in ovarian cancers (Additional file 3: Table S2). $n E R \beta 1$ correlated directly with cER $\beta 1(P=0.003), n E R \beta 5$
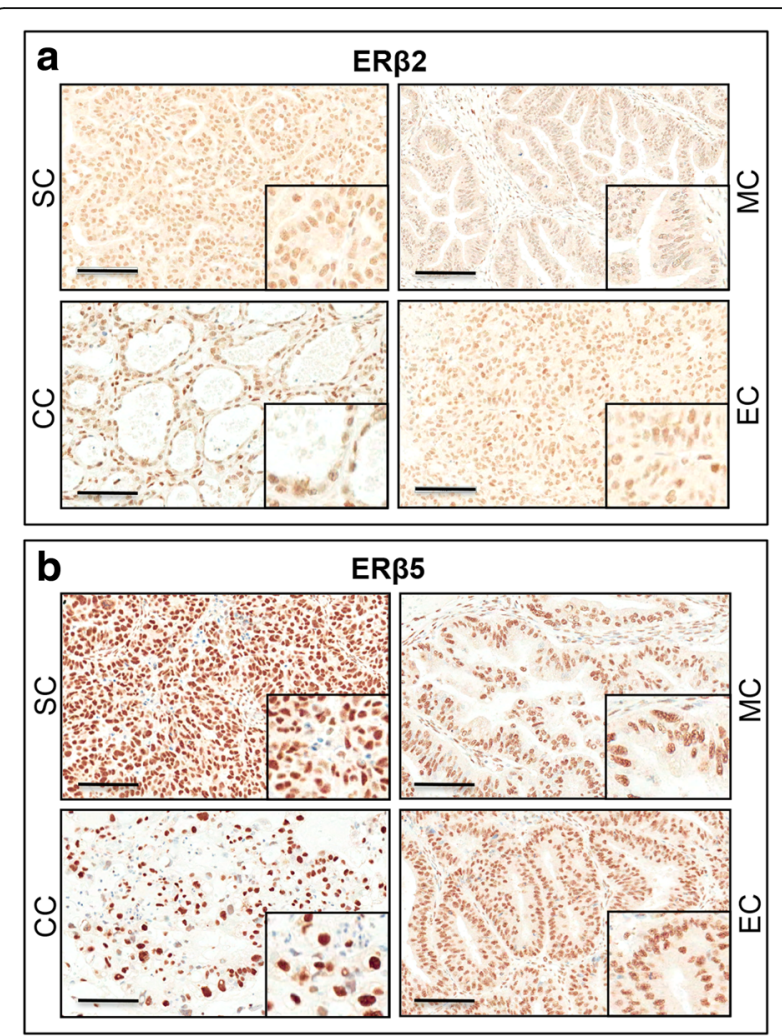

Fig. 2 Immunohistochemical staining of ERß2 (a) and ERß5 (b) in serous (SC), mucinous (MC), endometrial (EC) and clear cell (CC) carcinomas. Scale bar $=100 \mu \mathrm{m}$. Insets highlight regions with higher magnification

$(P=0.038)$. cER $\beta 1$ correlated directly with cER $\beta 2$ $(P=0.008)$ and $\operatorname{cER} \beta 5(P=0.001)$.

\section{Differential expression of ERs in three normal HOSE and eight ovarian cancer cell lines and their subcellular expression in SKOV-3 cells}

By immunoblotting, ER $\alpha$ was found in SKOV-3, but not in HOSE cell lines and other cancer cell lines (Fig. 4a). Similar expression of ER $\beta 1$ was detected in both normal and cancer cell lines. Higher ER $\beta 2$ expression was shown in SKOV-3, OVCAR-3, OVCA 429 and ES2 than HOSE 6-3. ER $\beta 5$ expression was demonstrated in SKOV-3, OVCAR-3, OVCA 429, TOV-21G and TOV112D, but not in HOSE cell lines. Western blot analysis revealed subcellular expression of $E R \alpha, E R \beta 1, E R \beta 2$ and ER $\beta 5$ in nuclear and cytoplasmic fractions of SKOV-3 (Fig. 4b).

\section{Overexpression of ER $\beta 5$ increased ovarian cancer cell invasion and proliferation in association with induced FAK activation}

Stable overexpression of ER $\beta 2$ and ER $\beta 5$ in ES-2 and OVCA420 was detected by immunoblotting using HisTag antibody (Fig. 5a). To further verify the specificity of ER $\beta 2$ and ER $\beta 5$ antibodies, immunoblotting was 
Table 1 Correlation of nucleus and cytoplasmic ERa and ERß1 with clinicopathological parameters in ovarian cancer

\begin{tabular}{|c|c|c|c|c|c|c|c|c|c|c|c|c|}
\hline \multirow[t]{2}{*}{ Characteristics } & \multirow[t]{2}{*}{ Case (n) } & \multicolumn{3}{|l|}{ Nucleus ERa } & \multicolumn{2}{|c|}{ Cytoplasmic ERa } & & \multicolumn{2}{|l|}{ Nucleus ERß1 } & & \multicolumn{2}{|c|}{ Cytoplasmic ERß1 } \\
\hline & & Mean \pm SD & $p$-value & & Mean \pm SD & $p$-value & & Mean \pm SD & $\overline{p \text {-value }}$ & & Mean \pm SD & $p$-value \\
\hline \multicolumn{13}{|l|}{ Stage (FIGO) } \\
\hline Early (I-II) & 49 & $3.71 \pm 3.32$ & & & $1.00 \pm 1.75$ & & & $5.60 \pm 1.94$ & & & $3.65 \pm 1.67$ & \\
\hline Late (III-IV) & 37 & $5.54 \pm 3.12$ & $0.012^{*}$ & $\uparrow$ & $0.22 \pm 0.92$ & $\underline{0.016^{*}}$ & $\downarrow$ & $6.35 \pm 1.64$ & $0.052^{*}$ & & $2.84 \pm 1.39$ & $0.101^{*}$ \\
\hline \multicolumn{13}{|l|}{ Histological grade } \\
\hline Low (1-2) & 56 & $4.11 \pm 3.48$ & & & $0.80 \pm 1.62$ & & & $6.25 \pm 1.97$ & & & $3.39 \pm 1.67$ & \\
\hline High (3) & 33 & $4.85 \pm 3.08$ & $0.370^{*}$ & & $0.36 \pm 1.17$ & $0.178^{*}$ & & $5.42 \pm 1.68$ & $\underline{0.046}^{*}$ & $\downarrow$ & $2.79 \pm 1.43$ & $\underline{0.046^{*}}$ \\
\hline \multicolumn{13}{|l|}{ Histology } \\
\hline Serous & 35 & $5.43 \pm 3.15$ & & & $0.34 \pm 1.14$ & & & $6.40 \pm 1.94$ & & & $2.91 \pm 1.46$ & \\
\hline Clear Cell & 17 & $1.06 \pm 2.02$ & & & $0.71 \pm 1.58$ & & & $6.76 \pm 1.64$ & & & $3.06 \pm 1.78$ & \\
\hline Mucinous & 9 & $2.22 \pm 2.73$ & & & $0.44 \pm 1.33$ & & & $5.56 \pm 2.46$ & & & $3.44 \pm 2.40$ & \\
\hline Endometrioid & 29 & $5.90 \pm 2.68$ & $\leq 0.001^{\dagger}$ & & $1.10 \pm 1.82$ & $0.230^{\dagger}$ & & $5.20 \pm 1.54$ & ${\underline{0.021^{\dagger}}}^{+}$ & & $3.40 \pm 1.35$ & $0.567^{\dagger}$ \\
\hline Serous/Clear Cell & 52 & $4.00 \pm 3.49$ & & & $0.46 \pm 1.29$ & & & $6.52 \pm 1.84$ & & & $2.96 \pm 1.56$ & \\
\hline Mucinous/Endometrioid & 38 & $5.05 \pm 3.09$ & $0.143^{*}$ & & $0.95 \pm 1.72$ & $0.129^{*}$ & & $5.28 \pm 1.76$ & $\underline{0.003^{*}}$ & $\downarrow$ & $3.41 \pm 1.62$ & $0.157^{*}$ \\
\hline Clear Cell & 17 & $1.06 \pm 2.02$ & & & $0.71 \pm 1.58$ & & & $6.76 \pm 1.64$ & & & $3.06 \pm 1.78$ & \\
\hline Non-Clear Cell & 73 & $5.23 \pm 3.10$ & $\leq 0.001^{*}$ & $\uparrow$ & $0.66 \pm 1.49$ & $0.905^{*}$ & & $5.81 \pm 1.92$ & $0.053^{*}$ & & $3.18 \pm 1.56$ & $0.593^{*}$ \\
\hline \multicolumn{13}{|l|}{ Chemosensitivity $^{\mathrm{a}}$} \\
\hline Sensitive & 63 & $4.64 \pm 3.12$ & & & $0.76 \pm 1.58$ & & & $6.12 \pm 1.93$ & & & $3.14 \pm 1.70$ & \\
\hline Resistant & 13 & $4.38 \pm 3.97$ & $0.885^{*}$ & & $0.31 \pm 1.11$ & $0.325^{*}$ & & $5.85 \pm 1.46$ & $0.609^{*}$ & & $2.77 \pm 0.73$ & $0.409^{*}$ \\
\hline
\end{tabular}

Those with significant $P$-values are underlined. $\uparrow$ Increase expression. $\downarrow$ Decrease expression

${ }^{*}$ Mann-Whitney test; ${ }^{\top}$ Kruskal-Wallis rank test

${ }^{a}$ Chemosensitive-patients remained disease free more than 6 months after completion of first-line chemotherapy

Intensity values are expressed as "Histoscores" as specified in Methods

performed on OVCA420 cells after stable overexpression of ER $\beta 2$ and ER $\beta 5$. By using anti-ER $\beta 2$ and anti-ER $\beta 5$ antibodies, increased expression of ER $\beta 2$ and ER $\beta 5$ was detected (Additional file 4: Figure S2). Then, we examined the roles of ER $\beta 2$ and ER $\beta 5$ on cell migration and invasion. ES-2 stably transfected with ER $\beta 2$ and ER $\beta 5$ displayed a faster migration rate when compared to control cells by a wound healing assay (Fig. $5 \mathrm{~b}$ ). Significantly increased migration and invasion $(P<0.05)$ in ER $\beta 2$ and ER 35 overexpressing ES-2 and OVCA420 cells was demonstrated by Transwell migration and invasion assays (Fig. 5c). Significantly increased migration and invasion in ER $\beta 2$ overexpressing TOV-21G cells was also detected $(P<0.05)$ (Additional file 5: Figure S3).

Next, we examined the possible downstream pathway of ER $\beta 5$. Focal adhesion kinase (FAK) and c-Src are key components of cell-matrix adhesion complexes, thus play important roles on cancer cell migration, invasion and metastasis [26]. We found ER $\beta 5$, but not ER $\beta 2$, induced FAK and c-Src activities as detected by phosphorylation on $\mathrm{Tyr}^{397}$ and $\mathrm{Tyr}^{416}$, respectively (Fig. 5a). To investigate the involvement of ER 35 -induced FAK activity on cell migration and invasion, overexpressing ER $\beta 5$ ES- 2 and OVCA420 cells were treated with a FAK inhibitor (5 $\mu \mathrm{M}$ FAK inh 14). We found that FAK inh 14 could inhibit FAK activation (Fig. 5d) and abolish not only basal, but also ER $\beta 5$-induced cell migration and invasion (Fig. 5d). We next investigated the effects on cell proliferation. By cell count method, ER $\beta 5$ significantly induced cell proliferation in ES-2 and OVCA420 cells after 8 and 9 days respectively (Fig. 6a), albeit no significant increase of cell proliferation on day 5 (early time point) as assessed by XTT assay (Additional file 6: Figure S4). By focus formation assay, the number of colonies from OVCA420 cells overexpressing ER $\beta 5$, but not ER $\beta 2$, increased by about $75 \%$ (Fig. 6b). Besides metastasis, FAK also promotes cell proliferation [27]. Thus, we sought to examine if ER $\beta 5$-induced FAK activation could affect cell proliferation. Intriguingly, FAK inh 14 (Fig. 6a) blocked the ER 35 -mediated increase in ES-2 and OVCA420 cell proliferation (Fig. 6a). FAK inh 14 also inhibited OVCA420 basal cell proliferation (Fig. 6a and Additional file 6: Figure S4).

\section{Discussion}

In the present study, we have shown ER $\alpha, E R \beta 1, E R \beta 2$ and ER $\beta 5$ expression in nucleus and cytoplasm of ovarian cancer cells. ERs classically mediate their effects by genomic pathway [18]. Our recent study has documented decreased cell growth in ER $\alpha / E R \beta 1$-expressing ovarian cancer cells, SKOV3 and OV2008, treated with MPP (ER $\alpha$ antagonist) and enhanced cell growth after treated with PPT (ER $\alpha$ agonist) [10]. An in vivo study 
Table 2 Correlation of nucleus and cytoplasmic ERß2 and ERß5 with clinicopathological parameters in ovarian cancer

\begin{tabular}{|c|c|c|c|c|c|c|c|c|c|c|c|c|}
\hline \multirow[t]{2}{*}{ Characteristics } & \multirow[t]{2}{*}{ Case (n) } & \multicolumn{2}{|c|}{ Nucleus ERß2 } & \multicolumn{2}{|c|}{ Cytoplasmic ERß2 } & & \multirow{2}{*}{$\begin{array}{l}\text { Nucleus ERß5 } \\
\text { Mean } \pm \text { SD }\end{array}$} & \multirow[b]{2}{*}{$p$-value } & \multicolumn{3}{|c|}{ Cytoplasmic ERß5 } & \\
\hline & & Mean \pm SD & $p$-value & Mean \pm SD & $p$-value & & & & & Mean \pm SD & $p$-value & \\
\hline \multicolumn{13}{|l|}{ Stage (FIGO) } \\
\hline Early (I-II) & 49 & $5.46 \pm 1.50$ & & $3.90 \pm 1.43$ & & & $6.61 \pm 1.10$ & & & $1.86 \pm 1.67$ & & \\
\hline Late (III-IV) & 37 & $5.65 \pm 1.60$ & $0.936^{*}$ & $3.78 \pm 1.40$ & $0.701^{*}$ & & $7.11 \pm 1.22$ & $\underline{0.030^{*}}$ & $\uparrow$ & $1.46 \pm 1.77$ & $0.165^{*}$ & \\
\hline \multicolumn{13}{|l|}{ Histological grade } \\
\hline Low (1-2) & 56 & $5.49 \pm 1.76$ & & $3.84 \pm 1.58$ & & & $6.88 \pm 1.06$ & & & $1.70 \pm 1.72$ & & \\
\hline High (3) & 33 & $5.64 \pm 1.27$ & $0.996^{*}$ & $3.88 \pm 1.32$ & $0.784^{*}$ & & $6.82 \pm 1.29$ & $0.751^{*}$ & & $1.67 \pm 1.80$ & $0.904^{*}$ & \\
\hline \multicolumn{13}{|l|}{ Histology } \\
\hline Serous & 35 & $5.80 \pm 1.68$ & & $4.06 \pm 1.24$ & & & $6.89 \pm 1.37$ & & & $1.40 \pm 1.77$ & & \\
\hline Clear Cell & 17 & $5.71 \pm 1.26$ & & $3.00 \pm 2.00$ & & & $7.29 \pm 1.11$ & & & $1.06 \pm 1.44$ & & \\
\hline Mucinous & 9 & $4.63 \pm 2.26$ & & $3.25 \pm 1.49$ & & & $6.22 \pm 0.67$ & & & $1.78 \pm 1.64$ & & \\
\hline Endometrioid & 29 & $5.40 \pm 1.35$ & $0.608^{\dagger}$ & $4.27 \pm 1.14$ & ${\underline{0.005^{\dagger}}}^{-}$ & & $6.70 \pm 0.92$ & $0.079^{\dagger}$ & & $2.33 \pm 1.73$ & $0.071^{\dagger}$ & \\
\hline Serous/Clear Cell & 52 & $5.77 \pm 1.54$ & & $3.71 \pm 1.59$ & & & $7.02 \pm 1.29$ & & & $1.29 \pm 1.66$ & & \\
\hline Mucinous/Endometrioid & 38 & $5.24 \pm 1.58$ & $0.237^{*}$ & $4.05 \pm 1.27$ & $0.246^{*}$ & & $6.59 \pm 0.88$ & $\underline{0.039^{*}}$ & $\downarrow$ & $2.21 \pm 1.70$ & $\underline{0.013^{*}}$ & $\uparrow$ \\
\hline Clear Cell & 17 & $5.71 \pm 1.26$ & & $3.00 \pm 2.00$ & & & $7.29 \pm 1.11$ & & & $1.06 \pm 1.44$ & & \\
\hline Non-Clear Cell & 73 & $5.51 \pm 1.64$ & $0.580^{*}$ & $4.05 \pm 1.25$ & $0.001^{*}$ & $\uparrow$ & $6.73 \pm 1.14$ & $0.095^{*}$ & & $1.82 \pm 1.77$ & $0.134^{*}$ & \\
\hline \multicolumn{13}{|l|}{ Chemosensitivity $^{\mathrm{a}}$} \\
\hline Sensitive & 63 & $5.56 \pm 1.57$ & & $3.64 \pm 1.36$ & & & $6.84 \pm 1.13$ & & & $1.67 \pm 1.72$ & & \\
\hline Resistant & 13 & $5.92 \pm 1.38$ & $0.595^{*}$ & $4.46 \pm 1.66$ & $0.105^{*}$ & & $6.92 \pm 1.12$ & $0.387^{*}$ & & $1.69 \pm 1.93$ & $0.846^{*}$ & \\
\hline
\end{tabular}

Those with significant $P$-values are underlined. $\uparrow$ Increase expression. $\downarrow$ Decrease expression

${ }^{*}$ Mann-Whitney test; ${ }^{\top}$ Kruskal-Wallis rank test

${ }^{a}$ Chemosensitive-patients remained disease free more than 6 months after completion of first-line chemotherapy Intensity values are expressed as "Histoscores" as specified in Methods
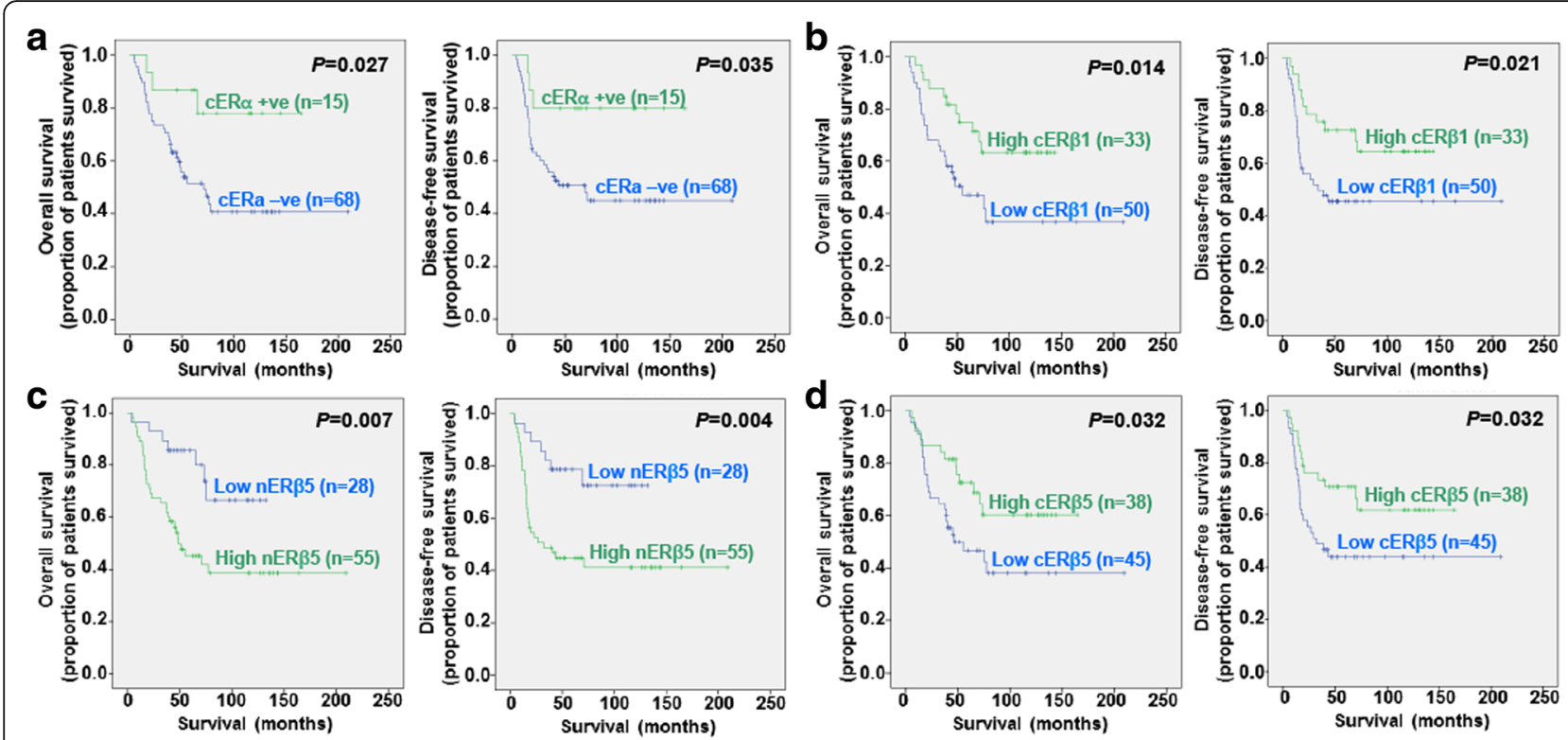

Fig. 3 Kaplan-Meier overall (left panel) and disease-free (right panel) survival curves for ovarian cancer patients with positive (histoscores $>0$ ) and negative cERa (a) expression, and high and low levels of cERß1 (b), nERß5 (c) and cERß5 (d) (cut off at mean) 
Table 3 Cox regression analysis for factors affecting overall survival

\begin{tabular}{llll}
\hline Prognostic factor & \multicolumn{3}{l}{ Overall survival } \\
\cline { 2 - 4 } & $P$ & Hazard Ratio & $95 \%$ Confidence Interval \\
\hline Nucleus ERß5 & 0.024 & 3.297 & $1.169-9.303$ \\
Disease stage & 0.008 & 3.831 & $1.411-10.402$ \\
Chemosensitivity & $<0.001$ & 12.984 & $4.681-36.011$ \\
\hline
\end{tabular}

also demonstrated that E2 significantly enhanced tumor size and promoted lymph node metastasis in $\mathrm{ER}^{+}$ ovarian tumors [28]. These findings together with our present data showing higher $\mathrm{nER} \alpha$ expression in advanced stages of disease suggested an aggressive role of $\mathrm{E} 2 / \mathrm{nER} \alpha$ signaling in ovarian cancer. Cytoplasmic ERs are also known to exert effects through non-genomic signaling, which may involve cross-talk with other growth-factor receptors or cytoplasmic kinases [18]. Specific cytoplasmic ER $\alpha$ staining has been detected in breast cancer clinical samples using multiple validated antibodies, albeit the average incidence was only $1.5 \%$ [29]. This study has validated multiple antibodies including the one that bind to the "SP1" epitope [29]. The present study using an antibody that recognizes "SP1" epitope also detected both nuclear and cytoplasmic staining in ovarian cancer clinical samples. We found a significant correlation between positive $\mathrm{cER} \alpha$ immunoreactivity and longer disease free and overall survival. Thus cER $\alpha$ could be a potential prognostic marker in ovarian cancer. A recent study showed that extranuclear ER $\alpha$ was involved in the regression of tamoxifen-resistant $\mathrm{PKC} \alpha$-overexpressing breast tumors [30]. It is possible that $\mathrm{cER} \alpha$ plays anti-oncogenic roles in ovarian cancer which will be studied in near future.

This study revealed lower $n E R \beta 1$ immunoreactivity in 16 metastatic foci than their paired primary cancers, suggesting that loss of $n E R \beta 1$ may contribute to ovarian cancer metastasis. This was in agreement with previous findings where overexpression of ER $\beta 1$ was shown to repress in vitro cell migration and invasion in ovarian cancer cells $[31,32]$ as well as reduce tumor formation in sites of metastasis in vivo [33]. Besides cell migration, ectopic overexpression of ER $\beta 1$ also inhibited proliferation of ovarian cancer cells which was accompanied by induced p21, a cyclin-dependent kinase inhibitor, and reduced cyclin A2 mRNA expressions [31, 34]. Moreover, we recently reported that ovarian cancer cells treated with DPN (ER $\beta 1$ agonist) suppressed cell growth in vitro and in vivo and was accompanied by inhibition of phosphorylation of AKT, a non-genomic signaling pathway [10]. All these findings together with our present data showing lower immunoreactivity of cER $\beta 1$ in advanced carcinomas and poor histological differentiation as well as correlation with poorer survival further support that ER $\beta 1$ present in the cytoplasm functions as a tumor suppressor in ovarian cancers $[20,35]$.

We also showed significantly higher nER 35 immunoreactivity in late stage disease and serous and clear cell histological subtypes. These findings suggest that nER $\beta 5$ affects the aggressiveness of the disease. Furthermore, a significant correlation between high nER $\beta 5$ immunoreactivity and poorer survival demonstrated $n E R \beta 5$ as a potential prognostic marker in ovarian cancer. In contrast to $\mathrm{nER} \beta 5$, we demonstrated $\mathrm{cER} \beta 5$ as a favorable prognostic marker in ovarian cancer. We further found lower cER $\beta 5$ immunoreactivity in late stage disease. In non-small cell lung cancer, a study also documented cER $\beta 5$ to be negatively correlated with pathological stage and predicted long overall and disease-free survival [36]. Our data suggested that while nER $\beta 5$ may have an oncogenic role in ovarian cancer, cER $\beta 5$ may have anti-oncogenic role. Studies on the functional roles of ER $\beta 2$ and ER $\beta 5$ in cancers are limited. ER $\beta 5$ in breast cancer cells has been found to enhance apoptosis induced by chemotherapeutic agent through Bcl2L12 interaction [37]. In prostate cancer cells, ER 35 increased cell migration and invasion [16]. A recent study has
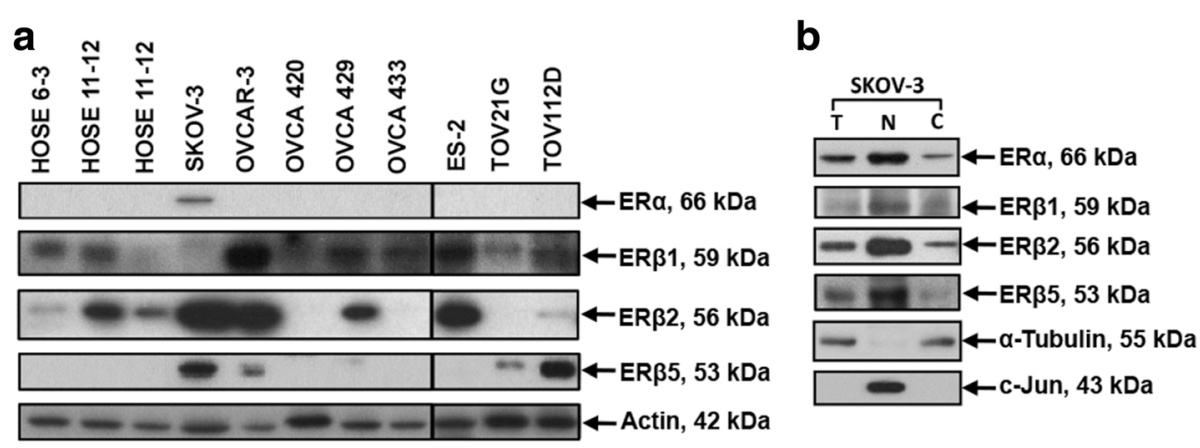

Fig. 4 a ERa, ERß1, ERß2 and ERß5 expression in immortalized human normal ovarian epithelial cell lines, HOSE 6-3, HOSE 11-12, HOSE 17-1 and ovarian cancer cell lines, SKOV-3, OVCAR-3, OVCA 420, OVCA 429 and OVCA 433, ES2, TOV-21G, TOV112D as determined by immunoblotting. Protein samples were resolved in two gels at the same time. $\mathbf{b}$ ERa, ERß1, ERß2 and ERß5 in subcellular protein fractions of SKOV-3 (T: total cell lysate, N: nuclear fraction, C: cytoplasmic fraction) 


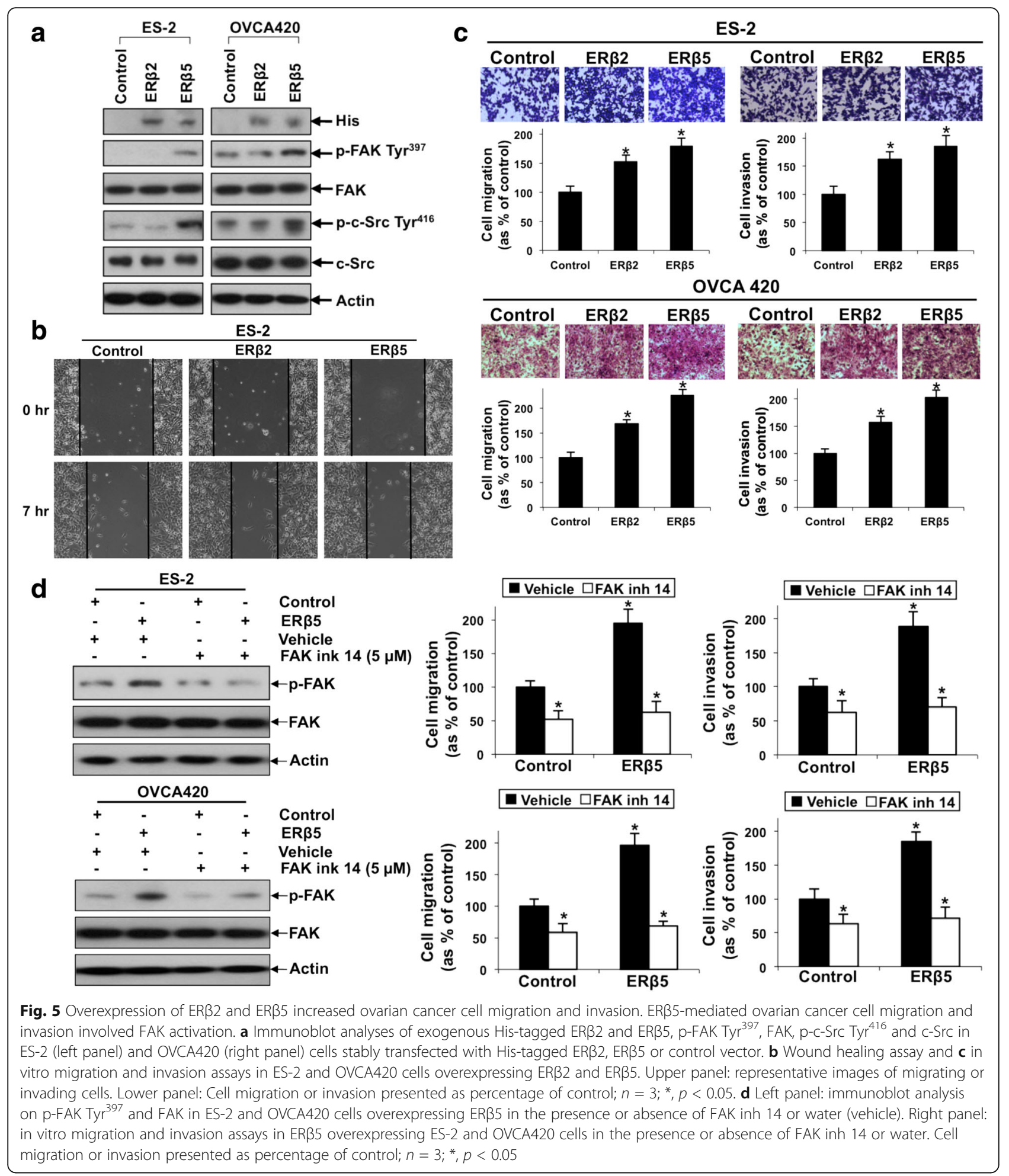

demonstrated antiapoptotic function of ER $\beta 2$ in advanced serious ovarian cancer [38]. In this study, we presented the first time the cell migration, invasion and proliferation enhancement roles of ER 35 in ovarian cancer cells. FAK, a cytoplasmic protein tyrosine kinase, has been shown to be overexpressed and activated in numerous solid cancers and is linked to poor prognosis including in ovarian cancer [39]. In preclinical studies, FAK inhibitors inhibited tumor growth and metastasis. A safe and well-tolerated FAK inhibitor has also been reported 


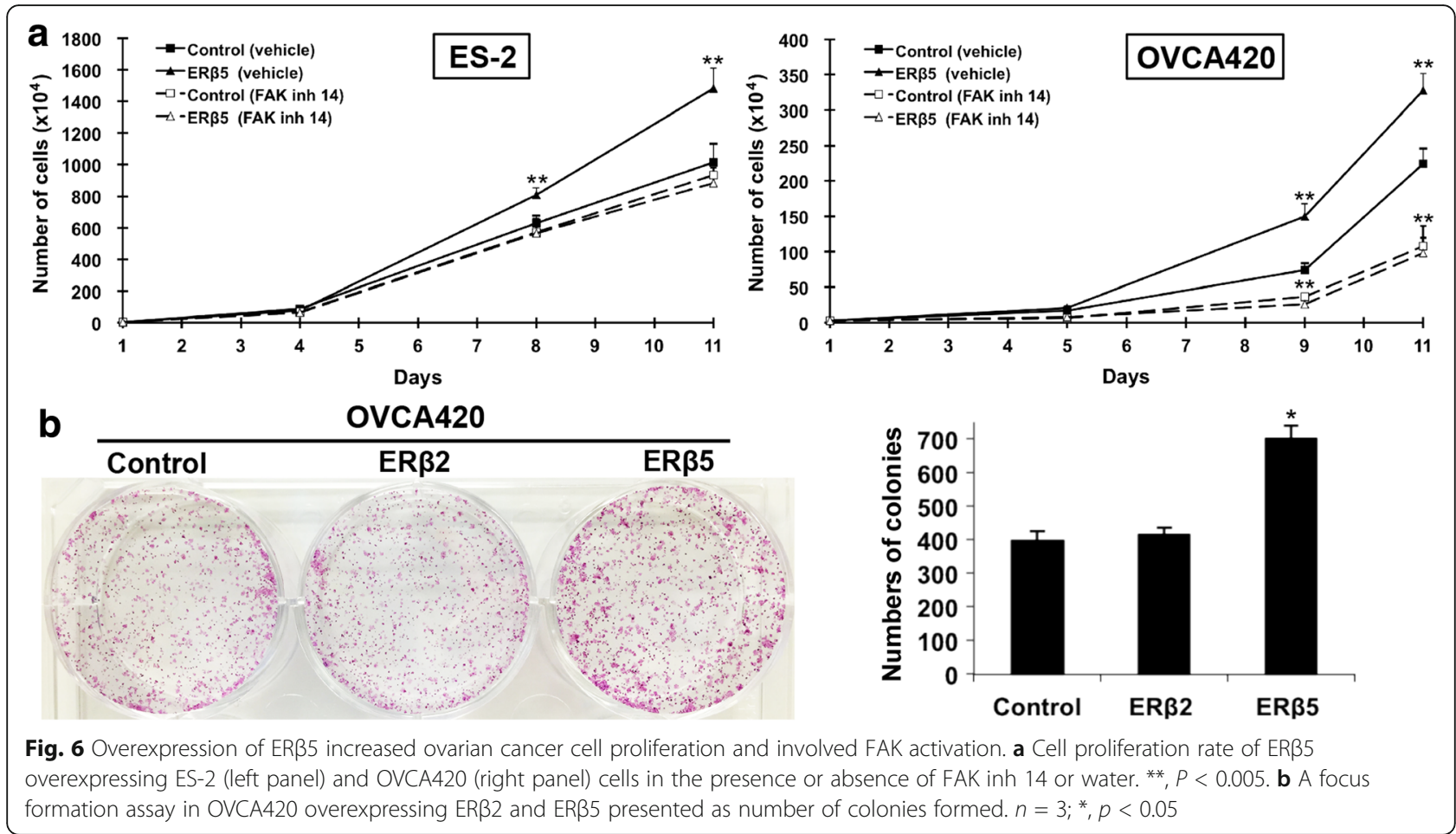

in a clinical trial study [39]. Moreover, activated FAK can form complex and activate c-Src [39]. Our present study demonstrated that ER $\beta 5$-induced cell migration, invasion and proliferation may involve FAK/c-Src activation in ovarian cancer. $\mathrm{nER} \beta 5$ may have an oncogenic role, wherease cER $\beta 5$ may have anti-oncogenic role in ovarian cancer, yet, we detected activation of cytoplasmic tyrosine kinases FAK/c-Src by ER $\beta 5$. It is possible that the activation of $\mathrm{FAK} / \mathrm{c}-\mathrm{Src}$ is an indirect activation via $\mathrm{nER} \beta 5$ target genes, which will be studied in near future. Unlike ER $\beta 5$, ER $\beta 2$ was shown to affect ovarian cell migration and invasion, but not proliferation. It would be worthy to investigate the downstream target regulating ER $\beta 2$-induced ovarian cancer cell migration and invasion in future study.

Interestingly, the present study demonstrated differential ER subtypes and variants expression in different histological types of ovarian cancer. $\mathrm{nER} \alpha$ was barely detectable in clear cell histological subtype. Such observation has been reported by others and loss of ER $\alpha$ in clear cell tumor was related to hypermethylation $[40,41]$. We further detected significantly higher nER $\beta 1$ and nER $\beta 5$ as well as lower cER $\beta 5$ in serous/clear cell histological subtypes. Moreover, nER $\beta 1$ positively correlated with nER $\beta 5$ whereas cER $\beta 1$ positively correlated with cER $\beta 5$, suggesting ER $\beta 1$ and ER $\beta 5$ maybe tightly regulated. A recent Ovarian Tumor Tissue Analysis consortium study also revealed association between ER $\alpha$ expression and histotype-specific survival. ER $\alpha$ is an independent prognostic marker for endometrioid ovarian cancers [23].

\section{Conclusions}

There are now increasing evidence to suggest that targeting individual ER subtypes by new SERMs with different $E R \alpha / E R \beta 1$ binding affinities can maximize the hormonal response $[3,10,42]$. The differential ER $\alpha$ and ER $\beta 1$ expression in ovarian cancer and in different histological types as shown in the present study may help to explain the poor response rate of tamoxifen (10-15\%) in ovarian cancer because tamoxifen binds to both ER $\alpha$ and ER $\beta 1$ and most clinical studies using tamoxifen therapy included patients with all histotypes [43, 44]. Moreover, our findings showed ER $\beta 5$ plays an important role in ovarian tumorigenesis by regulating cell migration, invasion and proliferation via $\mathrm{FAK} / \mathrm{C}-\mathrm{Src}$ activation. This study also suggests $\mathrm{nER} \beta 5$ as a potential prognostic marker and therapeutic target in ovarian cancer.

\section{Additional files}

Additional file 1: Table S1. Primary antibodies used for immunohistochemistry and immunoblotting. (DOC 43 kb)

Additional file 2: Figure S1. Box plot showing comparison of the median $\mathrm{nER} \beta 1$ immunoreactivity score in primary carcinomas versus matched metastatic foci. (PDF $69 \mathrm{~kb}$ )

Additional file 3: Table S2. Correlation coefficients between ERs expression in ovarian cancer. (DOC 55 kb)

Additional file 4: Figure S2. Immunoblot analyses of ERR2 and ERß5 in OVCA420 cells stably transfected with His-tagged ERß2, ERß5 or control vector. (PDF 57 kb) 
Additional file 5: Figure S3. Overexpression of ERß2 increased ovarian cancer cell migration and invasion. (a) Immunoblot analyses of exogenous His-tagged ERß2 in TOV-21G cells stably transfected with His-tagged ERß2 or control vector. (b) In vitro migration and invasion assays in TOV-21 G cells overexpressing ERß2. Upper panel: representative images of migrating or invading cells. Lower panel: Cell migration or invasion presented as percentage of control; $n=3 ;{ }^{*}, p<0.05$. (PDF $223 \mathrm{~kb}$ )

Additional file 6: Figure S4. XTT assay revealed lack of significant proliferation effect on day 5 in ES-2 and OVCA420 cells stably transfected with ERß5 as compared to control cells, whereas FAK inh 14 could inhibit OVCA420 basal cell proliferation on day 5. ns, not significant; ${ }^{*}, P<0.005$. (PDF $81 \mathrm{~kb})$

\section{Abbreviations}

ERs: Estrogen receptors; FAK: Focal adhesion kinase; SERMs: Selective estrogen receptor modulators

\section{Acknowledgements}

Not applicable.

\section{Funding}

The work was supported by the Hong Kong Research Grants Council General Research Fund (HKU761413) and the Wong Check She Charitable Foundation and the Research Fund from the Department of Obstetrics and Gynaecology, University of Hong Kong. The funders had no role in the study design, data collection and analysis, decision to publish, or preparation of the manuscript.

\section{Availability of data and materials}

The datasets used and/or analysed during the current study are available from the corresponding author on reasonable request.

\section{Authors' contributions}

Designed research: KC and MS; Acquisition and analysis of data: KC, MS, YJ, JW, YW, TL, SL, AC and HN; Wrote the paper: KC and MS. All authors read and approved the final manuscript.

\section{Ethics approval and consent to participate}

This study was approved by Institutional Review Board of the University of Hong Kong/Hospital Authority Hong Kong West Cluster (HKU/HA HKW IRB). Written informed consent was received from all patients.

\section{Consent for publication}

Not applicable.

\section{Competing interests}

The authors declare that they have no competing interests.

\section{Publisher's Note}

Springer Nature remains neutral with regard to jurisdictional claims in published maps and institutional affiliations.

\footnotetext{
Author details

'Department of Obstetrics and Gynaecology, The University of Hong Kong, Queen Mary Hospital, Hong Kong, HKSAR, China. ${ }^{2}$ Department of Pathology, The University of Hong Kong, Queen Mary Hospital, Hong Kong, HKSAR, China. ${ }^{3}$ Department of Pathology, The University of Hong Kong - Shenzhen Hospital, Shenzhen, China.
}

\section{Received: 22 August 2016 Accepted: 23 August 2017}

\section{Published online: 31 August 2017}

\section{References}

1. Siegel R, Ward E, Brawley O, Jemal A. Cancer statistics, 2011: the impact of eliminating socioeconomic and racial disparities on premature cancer deaths. CA Cancer J Clin. 2011;61(4):212-36.

2. Agarwal R, Kaye SB. Ovarian cancer: strategies for overcoming resistance to chemotherapy. Nat Rev Cancer. 2003;3(7):502-16.
3. Modugno F, Laskey R, Smith AL, Andersen CL, Haluska P, Oesterreich S. Hormone response in ovarian cancer: time to reconsider as a clinical target? Endocr Relat Cancer. 2012;19(6):R255-79.

4. Perez-Gracia $\mathrm{J}$, Carrasco EM. Tamoxifen therapy for ovarian cancer in the adjuvant and advanced settings: systematic review of the literature and implications for future research. Gynecol Oncol. 2002;84(2):201-9.

5. Kuiper GG, Enmark E, Pelto-Huikko M, Nilsson S, Gustafsson JA. Cloning of a novel receptor expressed in rat prostate and ovary. Proc Natl Acad Sci U S A. 1996;93(12):5925-30.

6. Mosselman S, Polman J, Dijkema R. ER beta: identification and characterization of a novel human estrogen receptor. FEBS Lett. 1996;392(1):49-53.

7. Lo R, Matthews J. A new class of estrogen receptor beta-selective activators. Mol Interv. 2010;10(3):133-6.

8. Chan KK, Wei N, Liu SS, Xiao-Yun L, Cheung AN, Ngan HY. Estrogen receptor subtypes in ovarian cancer: a clinical correlation. Obstet Gynecol. 2008;111(1):144-51.

9. Suzuki F, Akahira J, Miura I, Suzuki T, Ito K, Hayashi S, Sasano H, Yaegashi N. Loss of estrogen receptor beta isoform expression and its correlation with aberrant DNA methylation of the 5 '-untranslated region in human epithelial ovarian carcinoma. Cancer Sci. 2008;99(12):2365-72.

10. Chan KK, Leung TH, Chan DW, Wei N, Lau GT, Liu SS, Siu MK, Ngan HY. Targeting estrogen receptor subtypes (ERalpha and ERbeta) with selective ER modulators in ovarian cancer. J Endocrinol. 2014;221(2):325-36.

11. Leung YK, Mak P, Hassan S, Ho SM. Estrogen receptor (ER)-beta isoforms: a key to understanding ER-beta signaling. Proc Natl Acad Sci U S A. 2006; 103(35):13162-7.

12. Moore JT, McKee DD, Slentz-Kesler K, Moore LB, Jones SA, Horne EL, Su JL, Kliewer SA, Lehmann JM, Willson TM. Cloning and characterization of human estrogen receptor beta isoforms. Biochem Biophys Res Commun. 1998;247(1):75-8.

13. Wong NA, Malcomson RD, Jodrell DI, Groome NP, Harrison DJ, Saunders PT. ERbeta isoform expression in colorectal carcinoma: an in vivo and in vitro study of clinicopathological and molecular correlates. J Pathol. 2005;207(1):53-60.

14. Shaaban AM, Green AR, Karthik S, Alizadeh Y, Hughes TA, Harkins L, Ellis IO, Robertson JF, Paish EC, Saunders PT, et al. Nuclear and cytoplasmic expression of ERbeta1, ERbeta2, and ERbeta5 identifies distinct prognostic outcome for breast cancer patients. Clinical cancer research : an official journal of the American Association for Cancer Research. 2008; 14(16):5228-35.

15. Collins F, MacPherson S, Brown P, Bombail V, Williams AR, Anderson RA, Jabbour HN, Saunders PT. Expression of oestrogen receptors, ERalpha, ERbeta, and ERbeta variants, in endometrial cancers and evidence that prostaglandin $\mathrm{F}$ may play a role in regulating expression of ERalpha. BMC Cancer. 2009;9:330.

16. Leung YK, Lam HM, Wu S, Song D, Levin L, Cheng L, Wu CL, Ho SM. Estrogen receptor beta2 and beta5 are associated with poor prognosis in prostate cancer, and promote cancer cell migration and invasion. Endocr Relat Cancer. 2010;17(3):675-89.

17. Fujimura T, Takahashi S, Urano T, Ogawa S, Ouchi Y, Kitamura T, Muramatsu $M$, Inoue S. Differential expression of estrogen receptor beta (ERbeta) and its C-terminal truncated splice variant ERbetacx as prognostic predictors in human prostatic cancer. Biochem Biophys Res Commun. 2001;289(3):692-9.

18. Heldring N, Pike A, Andersson S, Matthews J, Cheng G, Hartman J, Tujague M, Strom A, Treuter E, Warner M, et al. Estrogen receptors: how do they signal and what are their targets. Physiol Rev. 2007;87(3):905-31.

19. Zhang G, Liu X, Farkas AM, Parwani AV, Lathrop KL, Lenzner D, Land SR, Srinivas $\mathrm{H}$. Estrogen receptor beta functions through nongenomic mechanisms in lung cancer cells. Mol Endocrinol. 2009;23(2):146-56.

20. Bardin A, Boulle N, Lazennec G, Vignon F, Pujol P. Loss of ERbeta expression as a common step in estrogen-dependent tumor progression. Endocr Relat Cancer. 2004;11(3):537-51.

21. Ciucci A, Zannoni GF, Travaglia D, Petrillo M, Scambia G, Gallo D. Prognostic significance of the estrogen receptor beta (ERbeta) isoforms ERbeta1, ERbeta2, and ERbeta5 in advanced serous ovarian cancer. Gynecol Oncol. 2014;132(2):351-9.

22. De Stefano I, Zannoni GF, Prisco MG, Fagotti A, Tortorella L, Vizzielli G, Mencaglia L, Scambia G, Gallo D. Cytoplasmic expression of estrogen receptor beta (ERbeta) predicts poor clinical outcome in advanced serous ovarian cancer. Gynecol Oncol. 2011;122(3):573-9.

23. Sieh W, Kobel M, Longacre TA, Bowtell DD, de Fazio A, Goodman MT, Hogdall E, Deen S, Wentzensen N, Moysich KB, et al. Hormone-receptor expression and ovarian cancer survival: an ovarian tumor tissue analysis consortium study. The lancet oncology. 2013;14(9):853-62. 
24. Siu MK, Chan HY, Kong DS, Wong ES, Wong OG, Ngan HY, Tam KF, Zhang H, Li Z, Chan QK, et al. p21-activated kinase 4 regulates ovarian cancer cell proliferation, migration, and invasion and contributes to poor prognosis in patients. Proc Natl Acad Sci U S A. 2010;107(43):18622-7.

25. Siu MK, Wong ES, Kong DS, Chan HY, Jiang L, Wong OG, Lam EW, Chan KK, Ngan HY, Le XF, et al. Stem cell transcription factor NANOG controls cell migration and invasion via dysregulation of E-cadherin and FoxJ1 and contributes to adverse clinical outcome in ovarian cancers. Oncogene. 2013;32(30):3500-9.

26. Zhao X, Guan JL. Focal adhesion kinase and its signaling pathways in cell migration and angiogenesis. Adv Drug Deliv Rev. 2011;63(8):610-5.

27. Ward KK, Tancioni I, Lawson C, Miller NL, Jean C, Chen XL, Uryu S, Kim J, Tarin D, Stupack DG, et al. Inhibition of focal adhesion kinase (FAK) activity prevents anchorage-independent ovarian carcinoma cell growth and tumor progression. Clinical \& experimental metastasis. 2013:30(5):579-94.

28. Spillman MA, Manning NG, Dye WW, Sartorius CA, Post MD, Harrell JC, Jacobsen BM, Horwitz KB. Tissue-specific pathways for estrogen regulation of ovarian cancer growth and metastasis. Cancer Res. 2010;70(21):8927-36.

29. Welsh AW, Lannin DR, Young GS, Sherman ME, Figueroa JD, Henry NL, Ryden L, Kim C, Love RR, Schiff R, et al. Cytoplasmic estrogen receptor in breast cancer. Clinical cancer research : an official journal of the American Association for Cancer Research. 2012;18(1):118-26.

30. Perez White B, Molloy ME, Zhao H, Zhang Y, Tonetti DA. Extranuclear ERalpha is associated with regression of T47D PKCalpha-overexpressing, tamoxifen-resistant breast cancer. Mol Cancer. 2013;12:34.

31. Treeck O, Pfeiler G, Mitter D, Lattrich C, Piendl G, Ortmann O. Estrogen receptor \{beta\}1 exerts antitumoral effects on SK-OV-3 ovarian cancer cells, J Endocrinol. 2007;193(3):421-33.

32. Zhu J, Hua K, Sun H, Yu Y, Jin H, Feng Y. Re-expression of estrogen receptor beta inhibits the proliferation and migration of ovarian clear cell adenocarcinoma cells. Oncol Rep. 2011;26(6):1497-503.

33. Bossard C, Busson M, Vindrieux D, Gaudin F, Machelon V, Brigitte M, Jacquard C, Pillon A, Balaguer P, Balabanian K, et al. Potential role of estrogen receptor beta as a tumor suppressor of epithelial ovarian cancer. PLoS One. 2012;7(9):e44787.

34. Cheng J, Lee EJ, Madison LD, Lazennec G. Expression of estrogen receptor beta in prostate carcinoma cells inhibits invasion and proliferation and triggers apoptosis. FEBS Lett. 2004;566(1-3):169-72.

35. Green CA, Peter MB, Speirs V, Shaaban AM. The potential role of ER beta isoforms in the clinical management of breast cancer. Histopathology. 2008:53(4):374-80

36. Liu Z, Liao Y, Tang H, Chen G. The expression of estrogen receptors beta2, 5 identifies and is associated with prognosis in non-small cell lung cancer. Endocrine. 2013:44(2):517-24.

37. Lee MT, Ho SM, Tarapore P, Chung I, Leung YK. Estrogen receptor beta isoform 5 confers sensitivity of breast cancer cell lines to chemotherapeutic agent-induced apoptosis through interaction with BCI2L12. Neoplasia. 2013;15(11):1262-71.

38. Ciucci A, Zannoni GF, Travaglia D, Scambia G, Gallo D. Mitochondrial estrogen receptor beta2 drives antiapoptotic pathways in advanced serous ovarian cancer. Hum Pathol. 2015;46(8):1138-46.

39. Sulzmaier FJ, Jean C, Schlaepfer DD. FAK in cancer: mechanistic findings and clinical applications. Nat Rev Cancer. 2014;14(9):598-610.

40. Fujimura M, Hidaka T, Kataoka K, Yamakawa Y, Akada S, Teranishi A, Saito S. Absence of estrogen receptor-alpha expression in human ovarian clear cell adenocarcinoma compared with ovarian serous, endometrioid, and mucinous adenocarcinoma. Am J Surg Pathol. 2001;25(5):667-72.

41. Yamaguchi K, Huang Z, Matsumura N, Mandai M, Okamoto T, Baba T, Konishi I, Berchuck A, Murphy SK. Epigenetic determinants of ovarian clear cell carcinoma biology. International journal of cancer Journal international du cancer. 2014:135(3):585-97.

42. Nilsson S, Koehler KF, Gustafsson JA. Development of subtype-selective oestrogen receptor-based therapeutics. Nat Rev Drug Discov. 2011;10(10):778-92.

43. Markman M, Iseminger KA, Hatch KD, Creasman WT, Barnes W, Dubeshter B. Tamoxifen in platinum-refractory ovarian cancer: a gynecologic oncology group ancillary report. Gynecol Oncol. 1996;62(1):4-6.

44. Trope C, Marth C, Kaern J. Tamoxifen in the treatment of recurrent ovarian carcinoma. Eur J Cancer. 2000;36(Suppl 4):S59-61.

\section{Submit your next manuscript to BioMed Central and we will help you at every step:}

- We accept pre-submission inquiries

- Our selector tool helps you to find the most relevant journal

- We provide round the clock customer support

- Convenient online submission

- Thorough peer review

- Inclusion in PubMed and all major indexing services

- Maximum visibility for your research

Submit your manuscript at www.biomedcentral.com/submit
Biomed Central 